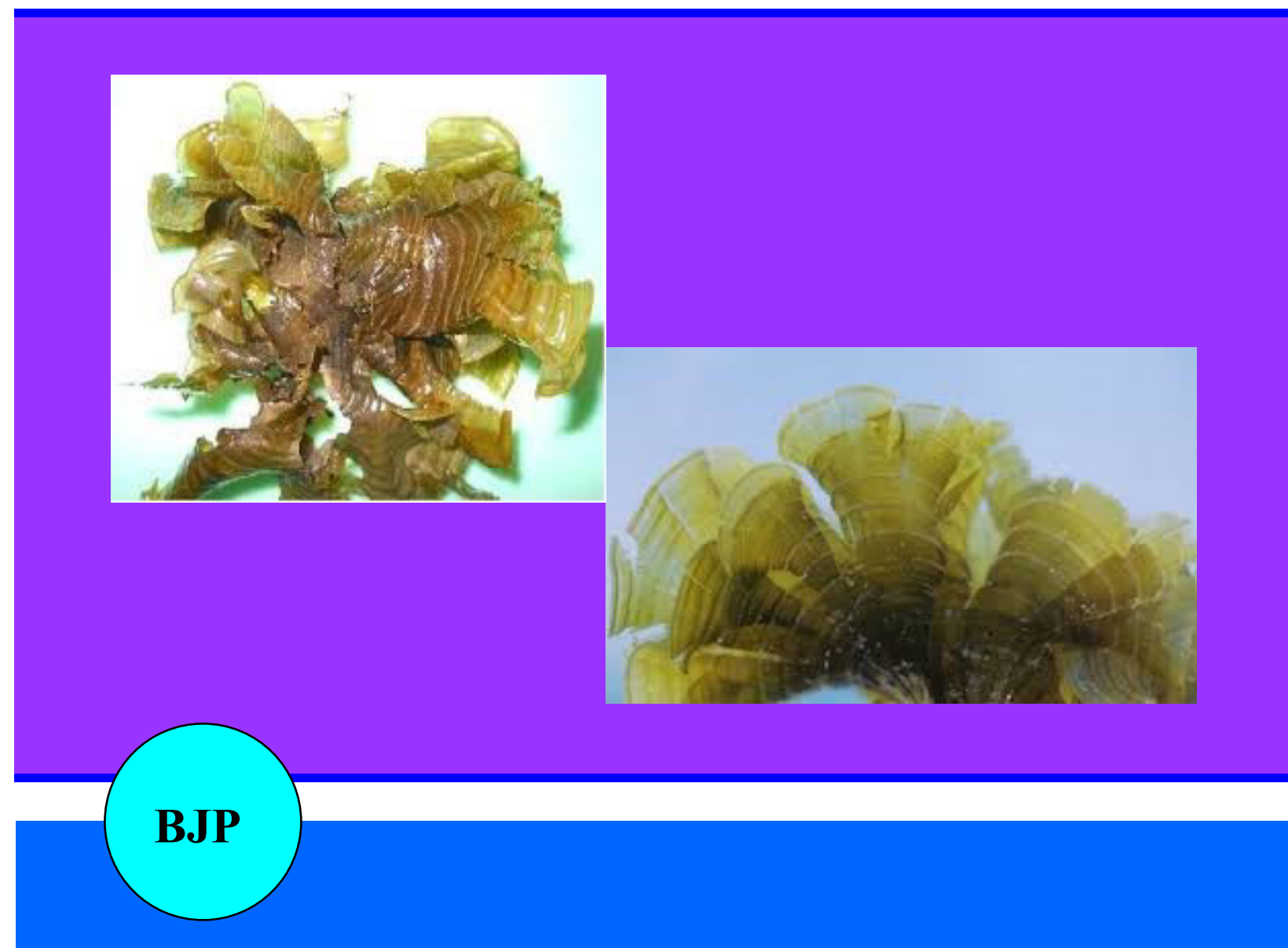

Bangladesh Journal of Pharmacology

Research Article

Attenuation of hyperglycemia and hyperlipidemia in high calorie fed/ streptozotocin-treated rats by hydromethanolic extract of Padina tetrastromatica 
Abstracted/indexed in Academic Search Complete, Agroforestry Abstracts, Asia Journals Online, Bangladesh Journals Online, Biological Abstracts, BIOSIS Previews, CAB Abstracts, Current Abstracts, Directory of Open Access Journals, EMBASE/Excerpta Medica, Global Health, Google Scholar, HINARI (WHO), International Pharmaceutical Abstracts, Open J-gate, Science Citation Index Expanded, SCOPUS and Social Sciences Citation Index

\title{
Attenuation of hyperglycemia and hyperlipidemia in high calorie fed/streptozotocin-treated rats by hydromethanolic extract of Padina tetrastromatica
}

\author{
Divya S. Mohan, Mini Saraswathy and Muraleedhara Kurup Gopala Kurup
}

Department of Biochemistry, University of Kerala, Kariavattom Campus, Thiruvananthapuram 695 581, Kerala, India.

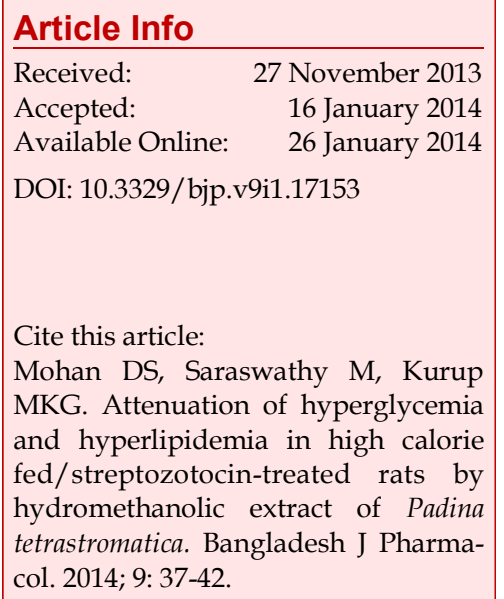

\section{Article Info}

Received:

Available Online: 26 January 2014

DOI: 10.3329 /bjp.v9i1.17153

col. 2014; 9: 37-42.

\begin{abstract}
In the present study, the effect of defatted hydromethanolic extract of Padina tetrastromatica on carbohydrate metabolism and serum lipid profile were evaluated. Diabetes mellitus was induced in male Wistar rats by feeding high calorie/energy diet for two months followed by a single intraperitoneal inject -tion of streptozotocin. Diabetic rats were administered with the extract intragastrically at doses of $150,300,450$, and $600 \mathrm{mg} / \mathrm{kg}$ body weight daily for 45 days. Treatment with graded doses showed a dose dependent reduction in blood glucose and glycated hemoglobin levels. Treatment significantly increased the activity of hexokinase, glucose-6-phosphate dehydrogenase and glyco -gen content while there was significant reduction in the activity of glucose-6phosphatase and fructose-1,6-bisphosphatase. Serum lipid profile was also brought back to near normal levels in a dose dependent manner. The present study clearly indicates the antihyperglycemic and hypolipidemic effects of $P$. tetrastromatica at an optimum dose of $450 \mathrm{mg} / \mathrm{kg}$ body weight.
\end{abstract}

\section{Introduction}

Type II diabetes mellitus is a progressive and multifaceted metabolic disorder characterized by hyperglycemia. The ideal treatment strategy should reverse insulin resistance and $\beta$-cell dysfunction and prevent or reverse long-term complications. Although lifestyle modifications are the basis of diabetes therapy, most patients will also require pharmacotherapy to achieve the better glycemic control, and in some cases they need exogenous insulin administration as well (Triplitt, 2007). But current pharmacotherapy are either too expensive or have serious side effects. In the present circumstances, search for economically and therapeutically effective alternatives is an upsurge. Due to ease of access, terrestrial sources, particularly plants are largely exploited for the development of anti-diabetic drugs. However, the research into the marine environment has gained more interest nowadays as they are more accessible and their chemical diversity become conscious. Marine algae have been identified as an under exploit-ted plant resource and a source of functional food (Nisizawa et al., 1987). Sea algae have been typically used as a health food and exhibit anti-diabetic effects (Kim et al., 2008). In addition, they are rich sources of structurally diverse bioactive compounds with great pharmaceutical and biomedical potential. In particular, the brown algae contain a variety of biological com-pounds, including pigments, phycocolloids and phloro-tannins (Halliwell and Gutteridge, 1999).

The brown alga Padina tetrastromatica (Phylum, Phaeophyta; Order, Dictyotales; Family, Dictyotaceae) is found in abundance in the coastal areas of India. Studies from our laboratory reported the anti-oxidant and anti-inflammatory potential of polysaccharides isolated from P. tetrastromatica (Mohsin et al., 2011; Mohsin and MuraleedharaKurup, 2011; Mohsin et al., 2013). However, no reports seem to be available on the effects of hydromethanolic extract of $P$. tetrastromatica in type II 
diabetes mellitus. Therefore, the present study was designed to investigate the anti-diabetic and hypolipide -mic effects of $P$. tetrastromatica extract in experimental diabetes mellitus.

\section{Materials and Methods \\ Seaweed material: P. tetrastromatica was collected freshly from the coastal rocks of Vizhinjam, Thiruvanantha- puram, South West coast of India (Lat. $8^{0} 22^{\prime} \mathrm{N}$; Long. $76059^{\prime}$ E) during the month of January-February. The seaweeds were identified by Dr. M.V.N Panikkar (Department of Botany, S. N. College, Kollam, Kerala, India). A voucher herbarium specimen (No. KUBH 5804) was deposited in the herbarium of Department of Botany, University of Kerala, India. Immediately after collection, the alga was thoroughly washed in running tap water to remove the epiphytes, sand and other extraneous matter and shade dried.}

Chemicals: All chemicals used in this study were of analytical grade and obtained from Sisco Research Laboratories (SRL), Mumbai.

Preparation of extracts: The algal extract was prepared according to the procedure of Kim et al. (2008). Alga (1 $\mathrm{kg}$ ) was soaked in $\mathrm{MeOH}: \mathrm{H}_{2} \mathrm{O}(8: 2, \mathrm{v} / \mathrm{v}, 1 \mathrm{~L})$ and extracted under conditions where the solvent was heated until reflux began, this being maintained for 3 hours. The residue was dissolved in $\mathrm{MeOH}: \mathrm{H}_{2} \mathrm{O}(8: 2$, $\mathrm{v} / \mathrm{v}, 500 \mathrm{~mL}$ ) and extracted twice as above, with the extracts individually filtered using Whatman No.1 paper. The combined supernatant was then concentrated under reduced pressure at a temperature of $40^{\circ} \mathrm{C}$. The concentrated extract was mixed with equal amount of distilled water and then partitioned using n-hexane: $\mathrm{H}_{2} \mathrm{O}$ (1:1) until the hexane layer becomes colourless and the aqueous layer was concentrated again to get a thick paste. The defatted extract was kept at $-20^{\circ} \mathrm{C}$ and used for the present study.

Experimental animals: Male Wistar rats from the same breed with a mean body weight of about $100 \mathrm{~g}$ were selected for the study. The animals were bred and kept in the animal house, Department of Biochemistry, University of Kerala. They were housed in polypropylene cages under standard environmental conditions ( 25 $\pm 2^{\circ} \mathrm{C} ; 12 / 12$ hours light/dark cycle). Prior to the beginning of the experiment, all rats were fed with basal diet at least for one week. Body weights of rats were recorded once in every two weeks. All studies were conducted after obtaining prior approval from the institutional ethics committee.

Experimental design: After 1 week of acclimatization, the animals were randomized into normal control and challenge groups. Rats in the normal control group were continually fed only normal laboratory food. Rats in the challenge group were given a high calorie/ energy diet (HCD) for two months. The HCD was prepared with a slight modification of the procedure of Wang et al., 2007, by adding $20 \%$ sucrose (w/w) and
$10 \%$ groundnut oil $(\mathrm{w} / \mathrm{w})$ into the basal diet. All rats could eat and drink ad libitum. After two months of HCD feeding, streptozotocin (STZ) at a dose of $15 \mathrm{mg} /$ $\mathrm{kg}$ body weight (Zhang et al., 2003) in $0.1 \mathrm{M}$ citrate buffer ( $\mathrm{pH}$ 4.6) was injected intraperitoneally. Seventytwo hours after STZ injection, the fasting blood glucose levels were measured and animals having blood glucose values greater than $300 \mathrm{mg} / \mathrm{dL}$ were selected for further experimentation.

The six rats in the previous normal control group were continually given normal laboratory food and served as the normal control (Group I). The diabetic rats were randomly divided into five groups of six rats each and treated as Group II (diabetic control): diabetic rats receiving vehicle alone; groups III-VI: diabetic rats administered with the extract intragastrically at doses of $150,300,450$ and $600 \mathrm{mg} / \mathrm{kg}$ body weight respectively for 45 days. At the end of the experimental period the rats were fasted overnight and sacrificed. Blood and tissues were removed to ice cold containers for various biochemical estimations.

Biochemical estimations: Fasting blood glucose was monitored by glucometer (One Touch Horizon, Johnson and Johnson). Glycated hemoglobin was estimated using kit purchased from Beacon Diagonostics Pvt. Ltd. India (Trivelli et al., 1971). The hepatic and muscular glycogen content was estimated by the method (Carroll et al., 1956). Hepatic glycolytic enzyme hexokinase (EC 2.7.1.1) was assayed by the method described (Crane and Sols, 1953). The activity of hepatic gluconeogenic enzymes glucose-6-phosphatase (EC 3.1.3.9) and fructose-1, 6-bis phosphatase (EC 3.1.3.11) were determined following the procedures (Robert et al., 1966 and Pontremoli, 1966). Activity of glucose-6-phosphate dehydrogenase (EC 1.1.1.49) was assayed by the method of Kornberg et al., 1955. Serum cholesterol was estimated by the cholesterol oxidase peroxidase method using the kit from Agappe diagonostics, India (Allain et al., 1974). Serum high density lipoprotein cholesterol was estimated by the cholesterol oxidase peroxidase method after precipitation using the kit from Agappe Diagonostics, India and the other lipoprotein fractions were calculated using Friedewald equation (Friedewald et al., 1972). Serum triglycerides were estimated by the GPO-PAP-ESPAS methodology using the kit from Agappe Diagonostics, India (Bucolo and David, 1973).

Statistical analysis: Statistical analysis was performed by one-way analysis of variance (ANOVA) followed by Duncan's multiple range test (DMRT) using Statistical Package for Social Science (SPSS) version 17.0. Results were expressed as mean \pm SD for six rats in each group. ' $\mathrm{p}$ ' values $<0.05$ were considered significant.

\section{Results}

Two months of HCD feeding resulted in the development of insulin resistance, which was confirmed by the 


\begin{tabular}{|c|c|c|c|c|}
\hline \multicolumn{5}{|c|}{ Table I } \\
\hline \multicolumn{5}{|c|}{ Effect of $P$. tetrastromatica on FBG, $\mathrm{HbA}_{1 \mathrm{c}}$ and glycogen content } \\
\hline \multirow[t]{2}{*}{ Groups } & \multirow[t]{2}{*}{$\begin{array}{l}\text { Blood glucose } \\
\quad(\mathrm{mg} / \mathrm{dL})\end{array}$} & \multirow[t]{2}{*}{$\mathrm{HbA}_{1 \mathrm{c}}(\%)$} & \multicolumn{2}{|c|}{$\begin{array}{l}\text { Glycogen content } \\
\text { (mg/g wet tissue) }\end{array}$} \\
\hline & & & Liver & Skeletal muscle \\
\hline Normal control & $86.4 \pm 8.3^{a}$ & $4.3 \pm 0.4^{\mathrm{a}}$ & $1.1 \pm 0.1^{\mathrm{a}}$ & $1.3 \pm 0.1^{a}$ \\
\hline Diabetic control & $408.0 \pm 39.2^{b}$ & $10.7 \pm 1.0^{\mathrm{b}}$ & $0.6 \pm 0.1^{b}$ & $0.7 \pm 0.1^{b}$ \\
\hline Diabetic $+P$. tetrastromatica $(150 \mathrm{mg} / \mathrm{kg}$ body weight $)$ & $160.9 \pm 15.4^{c}$ & $7.5 \pm 0.7 \mathrm{c}$ & $0.8 \pm 0.1^{c}$ & $0.7 \pm 0.1^{b}$ \\
\hline Diabetic $+P$. tetrastromatica $(300 \mathrm{mg} / \mathrm{kg}$ body weight $)$ & $133.9 \pm 12.2^{\mathrm{d}}$ & $6.3 \pm 0.6^{\mathrm{d}}$ & $0.8 \pm 0.1^{c, d}$ & $0.8 \pm 0.1^{b, c}$ \\
\hline Diabetic $+P$. tetrastromatica $(450 \mathrm{mg} / \mathrm{kg}$ body weight $)$ & $114.7 \pm 11.0 \mathrm{~d}, \mathrm{e}$ & $5.4 \pm 0.5^{\mathrm{e}}$ & $0.9 \pm 0.1^{\mathrm{d}, \mathrm{e}}$ & $0.9 \pm 0.1 \mathrm{c}$ \\
\hline Diabetic $+P$. tetrastromatica $(600 \mathrm{mg} / \mathrm{kg}$ body weight $)$ & $106.6 \pm 10.2^{\mathrm{a}, \mathrm{e}}$ & $5.3 \pm 0.5^{\mathrm{e}}$ & $1.0 \pm 0.1^{\mathrm{e}}$ & $1.0 \pm 0.1^{\mathrm{d}}$ \\
\hline
\end{tabular}

Table II

Effect of $P$. tetrastromatica on activity of carbohydrate metabolizing enzymes

\begin{tabular}{|c|c|c|c|c|}
\hline Groups & Hexokinase $^{\circledR}$ & $\begin{array}{c}\text { Glucose-6- } \\
\text { phosphatase }\end{array}$ & F-1,6-BPase $\$$ & $\begin{array}{l}\text { G-6-P } \\
\text { DHase* }\end{array}$ \\
\hline Normal control & $21.2 \pm 2.0^{a}$ & $77.1 \pm 7.4^{\mathrm{a}}$ & $233.1 \pm 22.4^{\mathrm{a}}$ & $1.5 \pm 0.1^{\mathrm{a}}$ \\
\hline Diabetic control & $3.6 \pm 0.3^{b}$ & $380.7 \pm 36.5^{b}$ & $272.5 \pm 26.1^{b}$ & $0.6 \pm 0.1^{b}$ \\
\hline Diabetic $+P$. tetrastromatica $(150 \mathrm{mg} / \mathrm{kg}$ body weight $)$ & $9.1 \pm 0.9 \mathrm{c}$ & $287.5 \pm 27.9 \mathrm{c}$ & $263.7 \pm 25.3 \mathrm{a}, \mathrm{b}$ & $1.0 \pm 0.1^{\mathrm{c}}$ \\
\hline Diabetic $+P$. tetrastromatica $(300 \mathrm{mg} / \mathrm{kg}$ body weight $)$ & $12.01 \pm 1.2^{\mathrm{d}}$ & $228.8 \pm 21.9 \mathrm{~d}$ & $260.5 \pm 25.0^{a, b}$ & $1.2 \pm 0.1^{\mathrm{d}}$ \\
\hline Diabetic $+P$. tetrastromatica $(450 \mathrm{mg} / \mathrm{kg}$ body weight $)$ & $15.5 \pm 1.5 \mathrm{e}$ & $190.3 \pm 18.3 e$ & $254.3 \pm 24.4^{a, b}$ & $1.4 \pm 0.1 \mathrm{e}$ \\
\hline Diabetic $+P$. tetrastromatica $(600 \mathrm{mg} / \mathrm{kg}$ body weight $)$ & $19.7 \pm 1.9 \mathrm{a}$ & $109.1 \pm 10.5^{\mathrm{f}}$ & $250.5 \pm 24.0^{\mathrm{a}, \mathrm{b}}$ & $1.5 \pm 0.1^{\mathrm{a}, \mathrm{e}}$ \\
\hline
\end{tabular}

levels of fasting blood glucose (FBG) and serum triglyceride levels. Streptozotocin injection aggravated the situation by increasing the FBG above $300 \mathrm{mg} / \mathrm{dL}$. Treatment with the extract for 45 days resulted in a significant recovery of FBG level in a dose-dependent manner (Table I). A similar trend was observed in the level of percentage glycated hemoglobin (HbA1c) (Table I). However there were no statistically significant differences between the FBG and HbA1c levels of diabetic rats of the groups $\mathrm{V}$ and VI, which indicated that $450 \mathrm{mg} / \mathrm{kg}$ body weight is the optimum dose for obtaining good glycemic control. Hepatic and muscular glycogen content was found to be significantly reduced $(\mathrm{p}<0.05)$ when compared to the normal control. Treatment of diabetic rats with $P$. tetrastromatica extract significantly elevated the glycogen levels in respect to the diabetic control (Table I).

The activity of the hepatic glycolytic enzyme hexokinase was decreased $(p<0.05)$ in the diabetic control group when compared to the normal control (Table II). On the other hand, the activity of the gluconeogenic enzymes (glucose-6-phosphatase and fructose-1,6bisphosphatase) get increased $(\mathrm{p}<0.05)$ in the liver of diabetic control group as compared to the normal control (Table II). Administration of P. tetrastromatica extract to diabetic rats significantly restored the enzyme activities in a dose dependent manner. The activity of glucose-6-phosphate dehydrogenase was reduced in the diabetic control group, whereas treatment with the extract tends to restore the enzyme activity in a dose dependent manner (Table II).

Serum total cholesterol (TC) and triglyceride (TG) levels were significantly elevated $(p<0.05)$ in the diabetic control group in comparison to the normal control (Table III). Supplementation of the extract for 45 days resulted in a significant diminution of these parameters in a dose dependent manner. Other hyperlipidemic parameters like serum LDLc and VLDLc, were elevated significantly $(\mathrm{p}<0.05)$ in the diabetic group in respect to control (Table III). All these parameters were decreased significantly in the extract supplemented groups in a dose dependent manner. HDLc was decreased in the diabetic groups in respect to the control (Table III). After 45 days of $P$. tetrastromatica supplementation, the serum levels of HDLc were significantly elevated.

\section{Discussion}

In the present study, the pathophysiological conditions of human type II DM was demonstrated in experimental animals by feeding them with a HCD for two months followed by an intraperitoneal injection of 
Table III

Effect of $P$. tetrastromatica on serum lipid profile

\begin{tabular}{|c|c|c|c|c|c|}
\hline Groups & $\begin{array}{l}\text { Triglycerides } \\
\text { (mg/dL) }\end{array}$ & $\begin{array}{l}\text { Total cholesterol } \\
(\mathrm{mg} / \mathrm{dL})\end{array}$ & $\begin{array}{l}\text { HDLc } \\
(\mathrm{mg} / \mathrm{dL})\end{array}$ & $\begin{array}{c}\text { LDLc } \\
(\mathrm{mg} / \mathrm{dL})\end{array}$ & $\begin{array}{l}\text { VLDLc } \\
(\mathrm{mg} / \mathrm{dL})\end{array}$ \\
\hline Normal control & $32.0 \pm 3.1^{\mathrm{a}}$ & $45.1 \pm 4.3^{a}$ & $36.0 \pm 3.5^{\mathrm{a}}$ & $2.7 \pm 0.3^{a}$ & $6.4 \pm 0.6^{\mathrm{a}}$ \\
\hline Diabetic control & $113.3 \pm 10.9 \mathrm{~b}$ & $94.5 \pm 9.1^{b}$ & $21.7 \pm 2.1^{b}$ & $50.1 \pm 4.8^{b}$ & $22.7 \pm 2.2^{b}$ \\
\hline $\begin{array}{l}\text { Diabetic }+P . \text { tetrastromatica }(150 \mathrm{mg} / \mathrm{kg} \text { body } \\
\text { weight })\end{array}$ & $103.4 \pm 9.9 c$ & $83.6 \pm 8.0 c$ & $24.1 \pm 2.3^{b, c}$ & $38.8 \pm 3.7 c$ & $20.7 \pm 2.0 c$ \\
\hline $\begin{array}{l}\text { Diabetic }+P . \text { tetrastromatica }(300 \mathrm{mg} / \mathrm{kg} \text { body } \\
\text { weight) }\end{array}$ & $93.2 \pm 8.9 \mathrm{~d}$ & $71.6 \pm 6.9 \mathrm{~d}$ & $26.7 \pm 2.6^{c, d}$ & $26.3 \pm 2.6^{d}$ & $18.6 \pm 1.8^{\mathrm{d}}$ \\
\hline $\begin{array}{l}\text { Diabetic }+P . \text { tetrastromatica }(450 \mathrm{mg} / \mathrm{kg} \text { body } \\
\text { weight })\end{array}$ & $83.9 \pm 8.1^{\mathrm{d}}$ & $62.0 \pm 5.9 \mathrm{e}$ & $27.7 \pm 2.7 \mathrm{~d}, \mathrm{e}$ & $17.5 \pm 1.8 \mathrm{e}$ & $16.8 \pm 1.6^{\mathrm{d}}$ \\
\hline $\begin{array}{l}\text { Diabetic }+P . \text { tetrastromatica }(600 \mathrm{mg} / \mathrm{kg} \text { body } \\
\text { weight })\end{array}$ & $68.3 \pm 6.6 \mathrm{e}$ & $48.5 \pm 4.7 \mathrm{a}$ & $30.8 \pm 3.0 \mathrm{e}$ & $4.1 \pm 0.4^{\mathrm{a}}$ & $13.7 \pm 1.3^{e}$ \\
\hline
\end{tabular}

mild dose of STZ following the procedures described elsewhere (Wang et al., 2007; Zhang et al., 2003). From the preliminary physiological and biochemical observations, it was obvious that we succeeded in establishing the typical characteristics of human type II DM in experimental rats. The therapeutic potential of $P$. tetrastromatica was assessed by monitoring the carbohydrate and lipid metabolism parameters.

Two months of high energy feeding resulted in fasting blood glucose around $150 \mathrm{mg} / \mathrm{dL}$ and upon STZ injection, the values shoot above $300 \mathrm{mg} / \mathrm{dL}$. This may be due to the concerted action of insulin resistance and pancreatic $\beta$-cell damage. It was observed that treatment with graded doses of $P$. tetrastromatica extract for 45 days reduced the fasting glucose to normal level. The percentage of glycated hemoglobin also showed a similar pattern. There was no statistically significant difference in the fasting blood glucose and glycated hemoglobin between the groups treated with the extract at doses of 450 and $600 \mathrm{mg} / \mathrm{kg}$ body weight, suggesting that $450 \mathrm{mg} / \mathrm{kg}$ is the optimum dose for acquiring good glycemic control. The antihypergly-cemic effect of $P$. tetrastromatica can be attributed to the presence of phenolic compounds present in the extract. The phenolic compounds stimulates insulin secretion by the closure of $\mathrm{K}^{+}$-ATP channels, membrane depolarization and stimulation of $\mathrm{Ca}^{2+}$ influx, an initial key step in insulin secretion from the remnant $\beta$-cells or from regenerated $\beta$-cells (Sunil et al., 2012).

Liver glycogen level may be considered as the best marker for assessing anti-hyperglycemic activity of any drug (Grover et al., 2000). Depletion of hepatic glycogen in experimental diabetes mellitus may be attributed to the loss of glycogen synthetase activating system (Huang et al., 2006) and/or increased activity of glycogen phosphorylase and glucose-6-phosphatase in diabetic rats (Ahmed, 2005; Ahmed et al., 2006). In the present study, the hepatic glycogen level was significantly decreased in the diabetic control rats and upon treatment the values tend to restore near the normal range. This decrease may be attributed to the enhanced glycogen breakdown, decreased glucokinase and increased glucose-6-phosphatase activity. The increase in liver glycogen upon treatment can be ascribed to the increased insulin response which in turn promotes conversion of inactive form of glycogen synthetase to the active form and enhances conversion of blood glucose into glycogen. This effect is in accordance with the previous findings (El-Shenawy and Abdel-Nabi, 2006; Rawi, 2000; Lalhlenmawia et al., 2007). The skeletal muscle is another tissue that gives a considerable contribution for the control of glucose homeostasis, by increasing glucose uptake into its cells (myocytes). The skeletal muscle stimulated by insulin takes glucose from the blood, and utilises it to produce energy and/or store it as glycogen (Huang and Czech, 2007). In skeletal muscle, insulin resistance manifests itself primarily by decreased insulin stimulation of glycogen synthesis (Cline et al., 1999). In the present study, the impact of insulin resistance in skeletal muscle is evidenced by the low levels of glycogen. However, treatment with $P$. tetrastromatica extract restored the glycogen levels to normal in a dose dependent manner, which indicated its potential to combat insulin resistance. The depletion of muscular glycogen is also one of the factors responsible for the decreased body weight observed in diabetic control rats.

In an attempt to gain an insight into the underlying biochemical mechanisms involved in the antihyperglycemic effect of $P$. tetrastromatica, the activity of hepatic hexokinase, glucose-6-phosphatase, fructose-1,6-bisphosphatase and glucose-6-phosphate dehydrogenase were evaluated. Hexokinase, an important enzyme in the catabolism of glucose, was decreased in diabetic rats leading to reduced conversion of glucose to glucose-6phosphate (Brandstrup et al., 1957). Administration of the extract to diabetic rats resulted in a significant reversal in the activity of hexokinase. The decreased blood glucose in diabetic rats treated with the extract might also be a result of increased hepatic hexokinase 
activity. The gluconeogenic enzyme glucose-6-phosphatase is a crucial enzyme of glucose homeostasis because it catalyzes the ultimate biochemical reaction of both glycogenolysis and glyconeogenesis (Mithievre et al., 1996). Increased glucose-6-phosphatase activity in diabe -tic rats provides hydrogen, which binds with $\mathrm{NADP}^{+}$ to form NADPH and enhances the synthesis of fats from carbohydrates (Bopanna et al., 1997), and finally contributes to increased levels of glucose in blood. Increased hepatic glucose production in diabetes is asso -ciated with impaired suppression of the gluconeogenic enzyme fructose-1,6-bisphosphatase. Activation of gluconeogenic enzymes is due to the state of insulin deficiency because, under normal conditions, insulin functions as a suppressor of gluconeogenic enzymes (Pari and Satheesh, 2006). Treatment with P. tetrastromatica had beneficial effects on glucose concentration as well as sequential metabolic correlation between increased glycolysis and decreased glyconeogenesis, suggesting the possible biochemical mechanism through which glucose homeostasis is regulated. Glucose-6-phosphate dehydrogenase (G6PD) is the key enzyme in pentose phosphate pathway which helps in maintaining the normal blood glucose levels (Mayes, 2000). In STZinduced diabetic murine model, G6PD activity in liver reduces significantly which obstructs glucose utilization and leads to hyperglycemia (Ugochukwu and Babady, 2003). Treatment with $P$. tetrastromatica resulted in a significant restoration of the enzyme activity which could be due to increase in insulin production as this enzyme activity depends on insulin.

Diabetes mellitus is often linked with abnormal lipid metabolism and is considered as a major risk factor for the premature development of atherosclerosis and cardiovascular complications (Biddinger and Kahn, 2006; Saltiel and Kahn, 2001). Implicit in this study, HCD-fed rats which are already mildly hyperglycemic, become more susceptible to develop significant hyperglycemia and hyperlipidemia with the diabetogenic effect of STZ (Elsner et al., 2000; Mu et al., 2006), which are similar to human type II diabetes. Increased TG and TC are known markers of hyperlipidemia in HCD/STZ -induced diabetic mice (Rajkumar et al., 2005). $P$. tetrastromatica significantly reduced attenuated serum TG and TC and lipid profile suggesting a salutary effect on cardiovascular risks. The levels of lipoprotein cholesterol were also significantly brought back to near normal levels, which also strengthen the hypolipidemic effect of the alga. During diabetes, enhanced activity of the enzyme lipase increases lipolysis and releases more fatty acids into the circulation (Agardh et al., 1999).The increased fatty acid concentration also increases the $\beta$ oxidation of fatty acids, producing more acetyl Co-A and cholesterol during diabetes. In normal condition, insulin increases the receptor-mediated removal of LDL -cholesterol and decreased activity of insulin, during diabetes causes hypercholesterolemia. The ability of the extract to attenuate hyperglycemia and hyperlipidemia reduces the risk of vascular complications.

\section{Conclusion}

The study demonstrated the anti hyper-glycemic and antihyperlipidemic potential of $P$. tetrastromatica in experimental diabetes mellitus.

\section{Acknowledgements}

This research was supported by funding from the Kerala State Council for Science Technology and Environment (KSCSTE), Government of Kerala, India in the form of Junior Research Fellowship to Divya S. Mohan.

\section{References}

Agardh CD, Bjorgell P, Nlson EP, The effect of tolbutamide on lipoproteins and lipoprotein lipase and hormone sensitive lipase. Diabetes Res Clin Pract. 1999; 46: 99-108.

Ahmed OM, Abdel-Hamid H, Bastawy M, Hasona NA Antihyperglycemic effects of Plantago ispaghula seeds aqueous extracts in diabetic and hypercholesterolemic rats. J Egypt Ger Soc Zool. 2006; 51: 371-93.

Ahmed OM. The hypoglycemic effect of curcumin and esculetin and their probable mechanism of action in STZ-induced diabetic albino rats. J Egypt Ger Soc Zool. 2005; 46: 351-75.

Allain CC, Poon LS, Chan CSG, Richmond W, Fu PC. Enzymatic determination of total serum cholesterol. Clin Chem. 1974; 20: 470-75.

Biddinger SB, Kahn CR. From mice to men: Insights into the insulin resistance syndromes. Annu Rev Physiol. 2006; 68: 123-58.

Bopanna KN, Kannan J, Sushma G, Balaraman R, Rathod SP. Antidiabetic and antihyperglycemic effects of neem seed kernel powder on alloxan diabetic rabbits. Indian J Pharmacol. 1997; 29: 162-67.

Brandstrup N, Kirk JE, Bruni C. Determination of hexokinase in tissues. J Gerontol. 1957; 12: 166-71.

Bucolo G, David H. Quantitative determination of serum triglyceride by use of enzymes. Clin Chem. 1973; 19: 475-82.

Carroll NV, Longley RW, Roe JH. The determination of glycogen in liver and muscle by use of anthrone reagent. J Biol Chem. 1956; 220: 583-93.

Cline GW, Petersen KF, Krssak M, Shen J, Hundal RS, Trajanoski Z, Inzucchi S, Dresner A, Rothman DL, Shulman GI. Impaired glucose transport as a cause of decreased insulin-stimulated muscle glycogen synthesis in type 2 diabetes. N Engl J Med. 1999; 341: 240-46.

Crane RK, Sols A. The association of hexokinase with particulate fractions of brain and other tissue homogenates. J Biol Chem. 1953; 203: 273-92.

El-Shenawy NS, Abdel-Nabi IM. Hypoglycemic effect of Cleome droserifolia ethanolic leaf extract in experimental diabetes and on non-enzymatic antioxidant, glycogen, thyroid hormones and insulin levels. Diabetol Croat. 2006; 35-36.

Elsner M, Guldbakke B, Tiedge M, Munday R, Lenzen S. Relative importance of transport and alkylation for pancreatic $\beta$-cell toxicity of streptozotocin. Diabetologia 2000; 43: 1528-33.

Friedewald WT, Levy RI, Fredrickson DS. Estimation of the concentration of low-density lipoprotein cholesterol in plasma, without use of the preparative ultracentrifuge. Clin Chem. 1972; 18: 499-502. 
Grover JK, Vats V, Rathi SS. Antihyperglycemic effect of Eugenia jambolana and Tinospora cordifolia in experimental diabetes and their effects on key metabolic enzymes involved in carbohydrate metabolism. J Ethnopharmacol. 2000; 73: 461-70.

Halliwell B, Gutteridge JMC. Anti-oxidant defences, free radicals in biology and medicine. 3rd ed. Oxford Science, 1999, pp 105-59.

Huang S, Czech MP. The GLUT4 glucose transporter. Cell Metab. 2007; 5: 237-52.

Huang X, Vaag A, Hanson M, Weng J, Laurila E, Goop L. Impaired insulin stimulated expression of the glycogen synthase gene in skeletal muscle of type II diabetic patients in acquired rather than inherited. Clin Endocrin Metabol. 2006; 85: 1584-90.

Kim KY, Nama KA, Kurihara H, Kim SM. Potent a-glucosidase inhibitors purified from the red alga Grateloupia elliptica. Phytochemistry 2008; 69: 2820-25.

Kim MS, Kim JY, Choi WH, Lee SS. Effects of seaweed supplementation on blood glucose concentration, lipid profile, and anti-oxidant enzyme activities in patients with type 2 diabetes mellitus. Nutr Res Pract Summer. 2008; 2: 62-67.

Kornberg A, Horecker BL. Glucose-6-phosphate dehydrogenase, 6-phosphogluconic dehydrogenase. Methods Enzymology. Colowick SP, Kaplan NO (eds). Vol 1, New York, Academic Press, 1955, pp 323-27.

Lalhlenmawia H, Kumarappani CT, Bhattacharjec BB, Mondal S. Antidiabetic activity of Mallotus roxburghianus leaves in diabetic rats induced by STZ. Pharmacology 2007; 3: 244-54.

Mayes PA. The pentose phosphate pathway and other pathway of hexose metabolism. In: Harper's biochemistry. Murray RK, Granner DK, Mayes VW (eds.), USA, McGrawHill, 2000, pp 219-37.

Mithievre G, Vidal G, Zitovn C, Miriasian C. Glucose-6phosphatase mRNA and activity are increased to the same extent in liver and kidney of diabetic rats. Diabetes 1996; 45: 891-96.

Mohsin S, Muraleedhara Kurup G, Arun AR. Antiinflammatory and anti-oxidant effect of sulphated polysaccharide isolated from marine algae Padina tetrastromatica from Kerala coast. J Pharm Res. 2011; 4: 784-88.

Mohsin S, Muraleedhara Kurup G, Mahadevan R. Effect of Ascophyllan from brown algae Padina tetrastromatica on inflammation and oxidative stress in carrageenan induced rats. Inflammation 2013; (Accepted for publication).

Mohsin S, Muraleedhara Kurup G. Mechanism underlying the anti-inflammatory effect of sulphated polysaccharide from Padina tetrastromatica against carrageenan induced paw edema in rats. Biomed Prev Nutr. 2011; 1: 294-301.

Mu J, Woods J, Zhou YP, Roy RS, Li Z, Zycband E, Feng
Y, Zhu L, Li C, Howard AD, Moller DE, Thornberry NA, Zhang BB. Chronic inhibition of dipeptidyl peptidase-4 with a sitagliptin analog preserves pancreatic beta-cell mass and function in a rodent model of type 2 diabetes. Diabetes 2006; 55: 1695-1704.

Nisizawa K, Noda H, Kikuchi R, Watamaba T. The main seaweed foods in Japan. Hydrobiol J. 1987; 151: 5-29.

Pari L, Satheesh MA. Effect of pterostilbene on hepatic key enzymes of glucose metabolism in streptozotocin and nicotinamide-induced diabetic rats. Life Sci. 2006; 79: 641-45.

Pontremoli S. Fructose-1,6-diphosphatase I: Rabbit liver (crystalline). Methods enzymology. Wood AW (ed). Vol 9, New York, Academic Press, 1966, pp 625-31.

Rajkumar M, Uttam KD, Debidas G. Attenuation of hyperglyce -mia and hyperlipidemia in streptozotocin-induced diabetic rats by aqueous extract of seed of Tamarindus indica. Biol Pharm Bull. 2005; 28: 1172-76.

Rawi SM. Physiological and biochemical evaluation of certain plants extracts as antidiabetic agents. Egypt J Zool. 2000; 32: 112-17.

Robert C, Nordlie, William JA. Methods Enzymology. Wood WA (ed). Vol 9. New York, London. Academic Press, 1966, pp 619-25.

Saltiel AR, Kahn CR. Insulin signalling and the regulation of glucose and lipid metabolism. Nature 2001; 414: 799-806.

Sunil C, Duraipandiyan V, Agastian P, Ignacimuthu S. Antidiabetic effect of plumbagin isolated from Plumbago zeylanica L. root and its effect on GLUT4 translocation in streptozotocin-induced diabetic rats. Food Chem Toxicol. 2012;. 50: 4356-63.

Triplitt CL. New technologies and therapies in the management of diabetes. Am J Manag Care. 2007; 13: S47-S54.

Trivelli LA, Ranney HM, Lai HT. Hemoglobin components in patients with diabetes mellitus. N Engl J Med. 1971; 284: 353 -57 .

Ugochukwu NH, Babady NE. Antihyperglycaemic effect of aqueous and ethanolic extract of Gongronema latifolium leaves on glucose and glycogen metabolism in liver of normal and streptozotocin-induced diabetic rats. Life Sci. 2003; 73: 1925-38.

Wang HJ, Jin YX, Shen W, Neng J, Wu T, Li YJ, Fu ZW. Low dose streptozotocin (STZ) combined with high energy intake can effectively induce type 2 diabetes through altering the related gene expression. Asia Pac J Clin Nutr. 2007; 16 (Suppl 1): 412-17.

Zhang F, Ye C, Li G, Ding W, Zhou W, Chen G, Luo T, Guang M, Liu Y, Zhang D, Zheng S, Yang J, Gu Y, Xie X, Luo M. The rat model of type 2 diabetes mellitus and its glycometabolism characters. Exp Anim. 2003; 52: 401-07. 